УдК 338.1.

K. Mamonov,

Doctor of Economic Sciences, professor

O. M. Beketov National University of Urban Economy in Kharkiv

ORCID ID: 0000-0002-0797-2609

V. Troian,

postgraduate student of the Department of Enterprise and Business Administration

O.M. Beketov National University of Urban Economy in Kharkiv

ORCID ID: 0000-0002-2142-2873

DOI: $10.32702 / 2306-6814.2019 .20 .24$

\title{
THEORETICAL AND METHODOLOGICAL APPROACHES TO BRAND ASSESSMENT OF CONSTRUCTION ENTERPRISES
}

\author{
К. А. Мамонов, \\ А. е. н., професор, Харківський національний університет міського господарства імені О. М. Бекетова \\ B. І. Троян, \\ аспірант кафедри "Підприємництва та бізнес-адміністрування", \\ Харківський національний університет міського господарства імені О. М. Бекетова
}

\section{ТЕОРЕТИКО-МЕТОАИЧНІ ПІАХОАИ ЩОАО ОЦІНЮВАННЯ БРЕНАУ БУАІВЕАЬНИХ ПІАПРИЕМСТВ}

The practice of assessing brand management in construction in Ukraine is in a passive stage, but due to the entry into the Ukrainian market of foreign companies for which regular evaluation of their brand - the need for survival in a competitive environment, Ukrainian companies are beginning to pay more attention to the creation and formation of their competitive trading because of its high business image / rating. A modern toolkit based on appropriate approaches is used to form organizational and economic foundations. The article analyzes modern scientific approaches to assessing the economic potential of an enterprise, identifies the main trends and factors that affect the assessment of construction enterprises. The article is devoted to the study of theoretical and methodological assessments of branding of construction enterprises. The role and importance of innovation in ensuring the efficient operation of modern enterprises is emphasized. It is found that construction, especially innovative, is of great social importance and has a significant economic effect. The importance of determining the potential of innovative development of construction in general and construction enterprises in particular is substantiated. The purpose of this article is to systematically investigate the interpretation of the potential of innovative development of construction enterprises. The theoretical basis of the research is the scientific works of foreign and domestic scientists on the problems of identifying the essence of innovative development potential. A systematic study of the general characteristics of the construction company brand was conducted and the priority directions for choosing the development of the economic potential of the enterprises were determined. The necessity to understand the potential of the enterprise in the unity of all its elements, which are subject to the achievement of the overall goals of the enterprise, is substantiated.

The weight of the component of the brand in the potential of the construction industry enterprises is substantiated. Some aspects of the development of theoretical and methodological approaches to the estimation of the intellectual capital of construction enterprises are formulated. Existing theoretical and methodological approaches to the brand assessment of construction enterprises are analyzed.

Практика оцінювання бренд-менеджменту у будівництві в Україні знаходиться на пасивній стадії, але завдяки виходу на український ринок іноземних компаній, для яких регулярна оцінка свого бренду - необхідність для виживання в конкурентному середовищі, українські компанії все більше уваги починають приділяти створенню і формуванню своїх конкурентоздатних торговельних марок задля свого високого показника ділового іміджу/рейтингу. Для фор- 
мування організаційно-економічних засад застосовується сучасний інструментарій, який базується на відповідних підходах. Устатті проаналізовано сучасні наукові підходи до оцінки економічного потенціалу підприємства, визначено основні тенденції та фактори, що впливають на оцінювання будівельних підприємств. Статтю присвячено вивченню теоретико-методологічних щодо оцінювання бренду будівельних підприємств. Підкреслюється роль та значення інновацій у забезпеченні ефективної роботи сучасних підприємств. Встановлено, що будівництво, особливо інноваційне, має велике соціальне значення та має значний економічний ефект. Обгрунтовано важливість визначення потенціалу інноваційного розвитку будівництва загалом та будівельних підприємств зокрема. Мета цієї статті - систематизувати дослідження інтерпретації потенціалу інноваційного розвитку будівельних підприємств. Теоретичною основою дослідження є наукові праці зарубіжних та вітчизняних вчених з проблем виявлення сутності потенціалу інноваційного розвитку. Проведено систематичне вивчення загальної характеристики бренду будівельного підприємства та визначено пріоритетні напрями вибору розвитку економічного потенціалу підприємств. Обгрунтовано необхідність розуміння потенціалу підприємства в єдності всіх його елементів, що підлягають досягненню загальних цілей підприємства.

Аргументовано вагомість складової бренду в потенціалі підприємств будівельної галузі. Сформульовано окремі аспекти розвитку теоретико-методичних підходів до оцінювання величини інтелектуального капіталу будівельних підприємств. Проаналізовано існуючі теоретичні та методологічні підходи до оцінки бренду будівельних підприємств.

Key words: enterprise potential, evaluation, construction industry, resources, brand.

Ключові слова: потенціал підприємстВа, оцінка, будіВельна галузь, ресурси, бренд.

\section{INTRODUCTION}

The problem of development of potential capabilities of construction industry enterprises is one of the most important tasks in their activity. Construction as an industry occupies one of the leading positions in the industrial complex of the country and makes a huge contribution to the development of all sectors of the economy without exception. Improved building materials and structures, increases the industrialization and variety of prefabricated buildings and structures. New technological processes of construction production are emerging. In recent years, there has been a rapid and significant complication of construction sites, which is significantly influenced by the creation of new efficient technological processes and their complex mechanization and automation. Construction organizations have relationships with virtually all sectors of the economy and agencies that act as suppliers of materials, machine construction, or are customers (there are a large number of customer organizations in the country) and consumers of construction products. All functional sectoral and regional departments are involved in investment placement in the construction industry. Large reserves of construction production are placed in solving problems of increasing the efficiency of production and economic potential (VEP), which synthesize many theoretical, methodological problems of design, production of materials and structures and their placement for the needs of construction. The study of the theory and practice of the building complex, the analysis of the numerous reasons for deviation of the planned indicators from the achieved in volume and quality of construction products allow to confirm that the VEP is largely formed and determined at the stage of preparation of construction in the process of designing construction objects and methods of providing them ready materials and structures. To solve the existing problems in the industry today, it is necessary to develop and introduce new methods of development management, updating production capacity, development of modern types of building materials, as well as improving the competitiveness of domestic enterprises of the construction industry.

World experience, including the practice of managing economic processes in advanced market economies, shows that sectoral approaches have a significant place in the enterprise management system.

The development and use of a construction company brand in the context of its management is influenced by external factors, condition and transformation processes that occur in the construction field. In particular, according to experts, the problematic aspects of the construction industry are limited funds, low solvency of the population, high credit rates. Issues related to:

- ensuring the reliability of the functioning of the construction industry enterprises;

- formation of break-even activities of economic entities;

- seasonal nature of the works and reduction of construction time;

- improving the quality of construction products;

- identifying opportunities for the use of modern technologies, methods and models of construction projects;

- increase of investment attractiveness and competitiveness of construction enterprises;

- formation of a brand of construction enterprises, growth of their business reputation;

- sustainable use of the environment and environmental protection.

\section{AN OVERVIEW OF THE LATEST SOURCES OF RESEARCH AND PUBLICATIONS}

Researchers managing the economic potential of enterprises are engaged in such scientists as: V.V. Prokhorov, P. Ignatovsky, Yu.M. Derevyanko, O.V. Bozhanova 
Y.M. Aksyonov, I.Z. Dolzhansky, S.O. Kotyreva, N.S. Krasnokutskaya, Y. Lichkin, V.O. Mets, E.V. Popov, B.A. Reizberg, N.F. Riffa, L.S. Sosnenko, R.Yu. Simionov, A. Todosiychuk, O.S. Fedonin, T.V. Kharchuk, A.A. Shevchenko and others, but there is no uniqueness in certain categories and their methods. evaluation.

The purpose of the article is to outline the main methods for assessing the potential of construction enterprises in Ukraine.

In accordance with the stated goal, the following tasks were identified:

- define the concept of "economic potential of construction enterprises";

- structure the potential by elements;

- to summarize modern methodological approaches to the assessment of the economic potential of construction enterprises.

\section{PRESENTING MAIN MATERIAL}

To solve the problems in the construction sphere, it is proposed to reduce the level of influence of the permitting system, the bureaucratic component, and the introduction of simplified procedures: "construction permits can be obtained three times faster than today, the total number of approvals will be reduced by almost four times. the bureaucratic component is also reduced. substation, firefighters, environmentalists and other structures that carry out the audit will be involved only once - during the approval of town planning documentation. most preparatory work will be based on the reported principle. private homes, cottages can be built under the simplified approval procedure."

In the context of identifying the problematic aspects of the functioning of the construction sphere, A. Asaul points out that "in modern conditions, as an object of public administration, the concept of" building complex "not only does not reflect the essence of real economic relations, but also takes the form of economic abstraction."

M. Kamenetsky and L. Dontsova focus their attention on the problematic directions of development of the building complex, noting that "the building complex, understood as a structural element of the national economy, which has a corresponding public administration authority ceased to exist with the collapse of the Soviet administrative and planning system."

Some scientists, characterizing the problems that arise in the construction complex, emphasize that "in the conditions of market economy with limited financial resources of Ukrainian enterprises of the construction complex, the issue of finding sources of their financing, formation of rational investment structure" and ensuring investment activity at all levels becomes especially relevant (cross-sectoral, inter-regional, world)" [4; 8].

The directions for increasing the efficiency of functioning of the construction sphere are defined: improving the reliability of functioning of construction enterprises; ensuring contractual relations between all stakeholder groups operating in the construction sector; maintenance of break-even activity of construction enterprises; reducing the duration of construction on relevant construction projects; increase of competitiveness and investment attractiveness of construction enterprises; ensuring mobility of construction enterprises; brand formation and strengthening; reducing the risks arising from the implementation of construction projects.

The functioning of the construction sphere is affected by external conditions that are associated with: the formation and construction of a nation-state; development of market economy; democratization of the political system; the formation of civic.

The political aspects of the impact on the development of the state and the economy are emphasized by scientists.

The functioning of the construction sphere is influenced by the transformation processes that characterize internal and external conditions, their interconnections.

Of particular importance is the introduction of energyefficient technologies in the construction field, increasing the quality of construction products, reducing the impact of the bureaucratic apparatus, securing domestic and foreign investment, activating public housing programs, and counteracting raiding.

Enterprise potential as an economic system can be viewed from different points of view, based on the resource concept (as a set of resources and relationships between them), functional (as a set of functions that provide the realization of capabilities and capabilities), resource-targeted (as a set of resources and ability to achieve certain results, goals) and other concepts. Economic potential is in the process of reproducing through its prism elements such as labor and natural resources, capital and information. Resources are the basic elements of capacity that make it possible to realize the opportunities available. There are the following types of resources used: technical (features of production equipment, required materials); technological (dynamics of technology, presence of competitive ideas, scientific developments); personnel (qualification, demographic composition of employees, their ability to adapt to changing company goals); resources of the organizational structure of the management system (nature and flexibility of the management system); information (the nature of information about the capabilities of the enterprise in the internal environment, the possibility of its expansion); financial (capital composition, liquidity, ability to obtain loans).

Considerable attention economists have paid to the definition and justification of the main components of the economic potential of enterprises. There were different approaches to this issue. For example, some scientists identify the components of the economic potential through the principles of operating, financial and investment activities. Others are focusing on the research interests of all those involved in the operation of the enterprise, namely: owners, managers, staff, suppliers, counterparties and consumers, and the like. However, it is practically impossible to take into account the interests of all stakeholders. In the object components of the economic potential of the enterprise include: production potential; innovative potential (characterizes the capabilities of enterprise in the development and implementation of innovations); financial potential; the potential of play (characterizes the capabilities of the current system of 
formation and updating of fixed assets to ensure the necessary level of competitiveness of production of the enterprise); information capacity characterizes the capabilities of the created information database to ensure timely and full saturation of the enterprise reliable input, output, regulatory, operational information for decisionmaking in the process of economic activity of the enterprise and achieve the objectives of its development); infrastructure potential (characterizes the attractiveness of the location of the enterprise from the point of view of development of market infrastructure, transport, communications and other factors). To subject components of the economic potential of the enterprise include: scientific and technical potential (characterizes the ability of employees to carry out research and development aimed at improving production and technological processes, differentiation of products); marketing potential; the potential of the organizational management structure (characterizes the capabilities formed the organizational management structure to ensure the highest level of efficiency of functioning of enterprises in conditions of variability of the environment); human potential (the sum of the abilities and capabilities of personnel to ensure the effective operation [1;3].

It should be noted that the construction industry affects the development of other industries and the economy of the state. It provides economic growth and has a social effect, providing housing for the population. In the construction of a significant number of jobs, uses the products of other sectors, forms of investment attractiveness of projects and the competitiveness of the economy of the state. The importance of the construction sector indicated by scientists.

According to experts, the development of strategic directions of further development of regional building complex must take into account the interests of all stakeholders that will ensure the growth of performance and competitiveness of construction enterprises.

In the context of state characteristics and transformation processes that occur in the construction industry are of special importance the results of definition of indicators of activities of construction enterprises.

The study found that in 2011-2017 observed wavy trend of the index of construction products. So for 20112014 , there is a reduction of this indicator in 2015-2017 - growth. Throughout the period of the index of construction output increased by more than 5\% [1].

Throughout the period observed wavy trend of the index buildings where the periods of fall give way to periods of growth. Moreover, this dynamics is consistent with the trends of this indicator for non-residential buildings. The residential buildings index building products was characterized by a decrease in 2011-2012, growth in 2013 , falling to 2015 and increase in 2016-2017 Trends of the index of construction products for engineering structures correspond to the General changes of the indicator.

As a result of the analysis of volumes of construction works in 2011-2017 there are also wave-like trend. In 2011-2012 there is a growth of this indicator in 2013 2014-fall 2015-2017. - increase. Similar trends are observed in the volume of construction work for residential and non-residential buildings. The volume of construction works on engineering structures was characterized by reduction in 2011 - 2014, which was replaced by growth in 2015-2017.

For the investigated period is observed a growth of commissioned housing to $17.5 \%$. This is due to the increase adopted in the operation of housing with two or more apartments and housing in the dorms. Along with this, have slowed the process of reduction taken in maintenance of housing in single-family residential buildings by $11.4 \%$. The study determined the growth of commissioned housing in both the urban and rural areas for 2011-2017. And the highest weight put into operation the housing is defined in urban areas. A similar trend is observed with the number of apartments built.

During the presented period there was a reduction in the number of buildings and engineering structures almost 1.7 times. This is to try building enterprises in the conditions of transformational processes to reduce the level of unfinished construction, thus finishing the construction processes of the past. The greatest number of unfinished construction sites were observed in the buildings. The number of uncompleted construction of engineering structures within the studied period decreased [5; 7].

In comparison with other areas of economic activity in construction has mastered a significant amount of capital investment. Only in agriculture and industry, this indicator exceeded the construction sector. The volume of capital investments by sources of financing, the largest share was carried out at the expense of own funds of enterprises and organizations. Other sources were insignificant share: state funds; local funds; Bank loans and other borrowings from foreign investors; funds of domestic investment companies, funds, etc.; public funds for housing construction; other sources of funding. The largest share was capital investment in tangible assets. A significant proportion consists of capital investments in residential buildings; commercial buildings; engineering structures; machinery, equipment and inventory; vehicle. In other assets received small amount of capital investment: land; long-term biological assets of crops and livestock; other tangible assets; investments in intangible assets. The results of the analysis of the volume of capital investments by types of assets in certain areas in 2017 indicates that the majority of them goes to new assets. The proportion of mastered capital investment in assets that were in use and the cost of repair is insignificant. The volume of used capital investments for the implementation of cost improvement, improvement, reconstruction, modernization is $15 \%$ of the total amount. It should be noted that commercial capital investments in residential and non-residential buildings mainly in new assets [2].

The largest volume of capital investments in tangible and intangible assets in 2017 was observed in the regions Zakarpattya and Khmelnytskyi; the Lugansk and Chernivtsi; Ivano-Frankivsk and Kherson; Mykolayiv and Ternopil; Cherkasy; Zhytomyr and Rivne. The low specific weight of capital investments in tangible and intangible assets in 2017 was characterized Donetsk, Kirovograd, Kharkov, Poltava region. The amount of mastered capital investment in tangible assets by types of fixed assets in the regions of Ukraine in 2017 was characterized by the highest values in residential buildings by regions: 
Transcarpathian, Chernivtsi, Khmelnytsky, Kyiv, Volyn, Ivano-Frankivsk. Along with this, a minor proportion to the volume of capital investments by regions of Ukraine in residential buildings are determined by region: Donetsk, Zaporizhia, Dnipropetrovsk, Kirovohrad, Mykolaiv, Kherson. The largest amount of mastered capital investment in non-residential buildings was observed in the regions: Zhytomyr, Chernivtsi, Lugansk and Odessa. Minor amounts disbursed in capital investment in nonresidential buildings was determined regions: Donetsk, Zaporozhye, Kherson. The volume of used capital investments in engineering structures ranged from $5.6 \%$ in Volyn region to $30.5 \%$ in the Kherson region.

It should be noted that the construction takes up a significant proportion of capex in 2017 compared to the other fields of activity. Most of the volume of capital investments was observed in the Transcarpathian, Chernivtsi, IvanoFrankivsk, Kyiv regions. The lowest value of disbursed capital investments in construction observed in the Dnipropetrovsk, Donetsk; Zaporozhye, Kirovograd, Lugansk, Nikolaev and Kherson regions. It should be noted that the volume of capital investments for 2011-2017, growing on all types of assets. Only in the land, the volume decreased by $12 \%$. For $2011-$ 2017 volume of financing of capital investments grew in the following sources: local budgets; own funds of enterprises and organizations; funds of foreign investors; funds of the population for housing construction; - other sources of funding. Along with this, within the studied period decreased the following funding sources capital investment: the state budget; Bank loans and other loans.

In the whole of Ukraine, in 2011-2017, the volume of sold products is almost doubled. This is due to the positive shif ts that have taken place over the last two years compared to the previous ones in certain areas of the state's economy. At the same time, such dynamics are related to the inflation component, which affects the growth of money supply, but it does not contribute to the development of economic entities. A similar trend is observed in the construction sector, where the volume of sales increased by 1.9 times. This is due to the increase in sales of: construction of buildings; construction of structures; specialized construction work [11].

It should be noted that throughout Ukraine, there is an increase in equity, long-term liabilities and collateral, current liabilities and collateral. This was due to similar trends in the fields of agriculture, forestry and fisheries; industry; wholesale and retail trade; repair of motor vehicles and motorcycles; information and telecommunications; financial and insurance activities; education; health care and social assistance. Construction is seeing a leak in equity and an increase in long-term and current liabilities and collateral.

Thus, the research identified ambiguous trends observed in the construction field. They are associated with low productivity or loss, loss of production and economic potential, slowing down development trends, which are characterized by "leaching" of equity and increased liabilities of construction companies. At the same time, assets in construction, volumes of sales are growing. The tendencies presented are determined by the influence of extensive or destructive factors, in particular inflationary processes or negative externalities. In such circumstances, there is a need to use modern tools aimed at ensuring the development of construction companies. Therefore, it is proposed to develop and implement a brand formation and utilization strategy for entities operating in the construction field.

\section{CONCLUSIONS}

Effective development of enterprises is caused not only by the volume of resources, but also by their quality, structure, degree of balance of components, but also by the rationality of their use. When assessing the economic potential of an enterprise and the efficiency of its use, it is necessary to clearly understand the structure, the main characteristics of the constituent elements, their relationship and use in the production process, the place and role of tangible elements of economic potential, in relation to other components. Thus, on the basis of the generalizations, it is concluded that the processes of enterprise development are not defined and assume the influence of internal and external factors, which requires constant search and realization of new opportunities for enterprise activity.

References:

1. Panko, O. (2005), "Prospects and problems of investment policy of enterprises of construction complex of Ukraine in the conditions of market economy", The Empire of Building, Real Estate and Architecture: An AllUkrainian Journal, vol. 2, pp. 26-31.

2. Biba, V. (2013), "State and prospects of development of construction industry of Ukraine", Collection of scientific works (industry engineering, construction), vol. 4, pp 3-9.

3. Fedorenko, V. (2007), "The concept of the strategy of the complex of Ukraine for the period up to 2015". Economy and the state, vol. 1, pp. 3.

4. Anin, V. (2003), "Calculations of risks of investment projects in construction", Formation of market relations in Ukraine, vol. 6, pp. 18.

5. Kuzmenko, O. (2015), "Investment climate and investment attractiveness of Ukrainian regions", Economic Nobel Bulletin, vol. 1, pp. 46-54.

6. Svidryk, T. and Borschuk, I. (2006), "Financial risks in construction projects: nature, causes, insurance. Collection of scientific and technical works", Scientific Bulletin, vol. 6 , pp. $258-261$.

7. Bilega, O. (2010), "Basic principles of strategic analysis of construction industry enterprises", Agrarian Bulletin of the Black Sea, vol. 53, pp. 32-38.

8. Krysko, J. (2012), "Analysis of the environment of restructuring of enterprises of the construction industry", Economic analysis, vol. 10 (4), pp. 203-206.

9. Pasechnik, V. (2006), "Marketing of construction markets of Ukraine: current state and prospects", Marketing in Ukraine, vol. 4, pp. 55-60.

10. Seniv, B. (2010), "The current state and prospects of development of the construction industry of Ukraine", Innovative economy, 2010. vol. 3, pp. 19-24.

11. Sevka, V. (2009), "The sequence of development of the strategy of anti-crisis regulation of the construction industry", Economics of construction and urban economy, vol. 1 , pp. $41-50$.

Стаття надійшла до редакчї 08.10.2019 p. 